\title{
PRODUCTION AND EVALUATION OF JAM FROM UNPOLLINATED SIWI DATES (SHEES)
}

\author{
(Received:23.8.2007)
}

\author{
By \\ M. T.M. Assous, O.M.M. Radi and M.A. Atwa \\ Food Technology Research Institute, Agricultural Research Center, Giza, Egypt
}

\begin{abstract}
This study was carried out to utilize unpollinated Siwi dates (Shees) after removing the soluble tannins in preparing jam. Results indicated that unpollinated Siwi dates contained higher flesh weight, total acidity, fibers, ash and total phenols contents than those of the Samani dates. At the same time, Samani dates were higher in fruit weight and total sugars compared to those of the unpollinated Siwi dates. Results illustrated that blanching for $45 \mathrm{~min}$ at $100^{\circ} \mathrm{C}$ reduced total phenols content to $68.6 \%$ of its original value. Results indicated that storage of prepared jam for 6 months at room temperature caused slight decrease in total acidity, total soluble solids ( T.S.S.), viscosity ,total phenols and non-reducing sugar content and, slight increase in reducing sugars. Statistical analysis indicated that there was no significant difference in sensory evaluation of jam made with unpollinated Siwi dates and Samani date at $1: 1 \mathrm{wt} / \mathrm{wt}$ ratio and that made with Samani date only even after 6 months of storage.
\end{abstract}

Key words: blanching, date, jam, phenols, storage.

\section{INTRODUCTION}

Dates (Phoenix dactylifera) are considered one of the most popular fruits. Egypt produced about 1166.18 thousand ton dates, in 2004 representing about $22.4 \%$ of the total Arab production(Arab Organization for Agricultural Development,2005). Egyptian production of Siwi and Samani dates amounted to 178.161 and 89.562 thousand tons representing about $15.36 \%$ and $7.7 \%$ of the total Egyptian production in 2005. The unknown dates varieties represented $19.82 \%$ of the total production (Ministry of Agriculture and Land Reclamation 2006). The main part of these unknown dates were unpollinated dates and other unpollinated dates found in known varieties as Siwi, Samani and Amahat dates as reported by Nezam El-Din (1996). Dates pass through certain stages of maturity; kimri, khalal, rutab and tamr and could be consumed in the last three stages (Assous, 1999). Sawaya et al. (1982) mentioned that tannins dominate the stage of maturation in all cultivars and characterize the palatability of astringency which decreases upon maturation development.

Dowson and Aten (1962) showed that unpollinated date has no or an imperfect seed which never develops beyond the khalal (the hard, glossy, yellow or red) stage. The unpollinated Siwi dates are refused due to its high astringent taste. Nezam EL-Din (1988) reported that dipping Siwi dates, at khalal stage, in boiling water decreased total phenols and low molecular weight from 1.90 and 0.311 to 1.71 and $0.105 \%$ while high molecular weight tannins increased from 0.03 to $0.051 \%$. Abbas (1982) reported that T.S.S, total sugars, tannins and titratable acidity of Samani dates were 27.7, 26.4, 0.24 and $0.12 \%$, respectively. Rygg (1946) reported that artificial ripening of khalal unpollinated Deglet Noor dates (khalal stage) was suitable for use in maceration. The product may be blended with the macerated product of naturally ripened dates to make an acceptable mixture for use in cooking and making confectionaries. Also,Nezam El-Din(1996)utilized unpollinated Siwi dates in pickling .

This work was conducted to study the possibility of utilizing the unpollinated Siwi dates in food products (jam) after removing the tannins that are responsible for the astringency and the effect of storage at room temperature for 6 months on the keeping quality of jam.

\section{MATERIALS AND METHODS}

\subsection{Materials}

Unpollinated Siwi dates (Shees) at khalal stage were obtained from Abou-Rawash region, Giza, Egypt and Samani dates at the ripe stage were obtained from local market in Giza, Egypt, in season 2005.

The aspartame (Nutrasweet brand) was obtained from G.D. Searle and L.T.D.S.A. 


\subsection{Methods}

\subsubsection{Processing methods}

Unpollinated Siwi dates at khalal stage were weighed, washed, pitted before blanching in water for 15,30 and $45 \mathrm{~min}$ at $100^{\circ} \mathrm{C}$. Ratio of water to dates was $1.5: 1 \mathrm{wt} / \mathrm{wt}$. The blanching treatment time that gave the lowest total phenols and the highest T.S.S. was chosen to make the jam. Also, Samani dates at the ripe stage were weighed, washed, pitted and peeled before using in making jam.

2.2.1.1. Jam processing : Table (1) indicates the basic recipes of preparing date Jam. Processing of Jam and low calorie jam were terminated when T.S.S reached $\sim 68 \%$ and $<50 \%$, respectively.

2.2.1.2. Packaging and storage: Date jam was packed in glass jars. The date jam with high sensory scores (overall acceptability) was selected and stored at room temperature for 6 months.

\subsubsection{Analytical methods}

Moisture content was determined by the oven under vacuum at $60^{\circ} \mathrm{C}$, crude fiber, ash, acidity, minerals (Potassium, Sodium, Calcium, Iron, Zinc, and Copper) were determined according to A.O.A.C. (2000). Viscosity was measured by Brookfield Viscometer DV III Ultra Programmable Rheometer with spindle No. HA 07 for date jam at r.p.m. 10.0 and $30 \pm 1 \mathrm{C}^{\circ}$.

The $\mathrm{pH}$ value was measured using a Beckman $\mathrm{pH}$ meter with a combining electrode at $25^{\circ} \mathrm{C}$ and the T.S.S. was determine by Abbe refractometer according to A.O.A.C. method (2000). Total phenols were extracted according to the procedure described by Maier and Metzler (1965) and determined according to the method of Swain and Hillis (1959). Reducing sugars and total sugars were determined using Lane and Eynon method as described in the A.O.A.C. method (2000).

2.2.2.1. Sensory evaluation: Date Jam was subjected to sensory evaluation test. Ten panelists evaluated the samples according to the numerical scoring test. The panelist evaluated each sample on a specific scale from 1 to 10 for taste, color, texture and odor according to Ranganna (1977). Overall acceptability score $=$ taste + color + texture + odor scores for the sample divided by 4 . The results of sensory evaluation were statistically analyzed using Duncan multiple range test according to the method reported by Snedecor and Cochran (1980).

\section{RESULTS AND DISCUSSION}

The results in Table (2) show the physical and chemical characteristics of unpollinated Siwi dates at khalal stage and Samani dates at the ripe stage. From these data it could be noticed that the unpollinated Siwi dates were characterized by higher flesh weight and flesh/pits ratio than those of the Samani dates. On the other hand, the results in Table (2) indicate that the average weight (g)/fruit of Samani dates was3.2 times that of the unpollinated Siwi dates. Rizk (1987) showed that the average weight of the Samani dates was $32.17 \mathrm{~g}$.

Samani dates were characterized by high pit weight, T.S.S. and $\mathrm{pH}$ values. Also,the chemical characteristics indicated that Samani dates contained total sugars and reducing sugars content higher than those of the unpollinated Siwi dates. Also, the unpollinated Siwi dates contained crude fiber, ash, total phenols and total acidity higher than those of the Samani dates. These results are in agreement with those reported by Ragab et al. (1956) and Nezam El-Din (1996).

Results in Table (3) show the effect of blanching time on the physical and chemical characteristics of the unpollinated Siwi date. From these data, it could be noticed that extending blanching time was accompanied by an increase in T.S.S, total sugars, reducing sugars, non-reducing sugars and total acidity. Besides, total phenols, ash content and $\mathrm{pH}$ value were decreased by extending blanching time at $100^{\circ} \mathrm{C}$ from 15 to $45 \mathrm{~min}$. These results are in accordance with those reported by Bate-Smith (1977) and Yousif et al. (1982) who found that most of the soluble tannins were lost in the blanching process and the remaining tannins changed to condensed form. The soluble tannins are responsible of the astringency of the unpollinated Siwi date. Also, the results in Table (3) show that moisture content was increased from $72.93 \%$ ( fresh unpollinated Siwi date) to $78.76 \%$ after blanching for $15 \mathrm{~min}$. These results are in accordance with those obtained by Nezam El-Din (1996).On the other hand, it could be noticed that extending blanching time was accompanied by a decrease in moisture content. This may be due to the evaporation of moisture and /or leaching of some liquids from cell walls (Hamed, 1980 and Hassan, 1995). From the previous results in Table (3) it could be noticed that blanching for $45 \mathrm{~min}$ was effective in reducing total phenol content (as tannic acid )in the unpollinated Siwi date from $2.44 \%$ in the raw fruits to $1.23 \%$ in the blanched one.

Results in Table (4) illustrate the physical and chemical properties of date jam of different treatments. From these data, it could be observed that the control treatment prepared from Samani date was characterized by a high level of reducing sugars while,date jam of the treatment (1)prepared 
Table (1): Basic recipes of the prepared date Jam.

\begin{tabular}{|l|c|c|c|c|c|c|}
\hline \multicolumn{1}{|c|}{ Treatments } & Control & $\mathbf{1}$ & $\mathbf{2}$ & $\mathbf{3}$ & $\mathbf{4}$ & $\mathbf{5}$ \\
Ingredients(g) & & & & & & \\
\hline Samani date & 500 & - & - & 250 & 250 & 250 \\
Unpollinted Siwi date & - & 500 & 500 & 250 & 250 & 250 \\
Sucrose & 500 & 500 & 500 & 500 & 250 & - \\
Pectin & 1.5 & 1.5 & 1.5 & 1.5 & - & - \\
Citric acid & 1.5 & 1.5 & 1.5 & 1.5 & 1.5 & 1.5 \\
Cloves & - & - & 2.5 & - & - & - \\
Low methoxyl pectin & - & - & - & - & 0.8 & 0.8 \\
Calcium chloride & - & - & - & - & 0.1 & 0.1 \\
Sodium benzoate & - & - & - & - & 0.3 & 0.3 \\
Sodium sorbate & - & - & - & - & 0.2 & 0.2 \\
Aspartame & - & - & - & - & 1.38 & 2.77 \\
\hline
\end{tabular}

Table (2): Physical and chemical characteristics of unpollinated Siwi dates at khalal stage and Samani dates at the ripe stage.

\begin{tabular}{|l|c|c|}
\hline Characteristics & $\begin{array}{l}\text { Unpollinated } \\
\text { Siwi dates } \\
\text { (khalal stage) }\end{array}$ & $\begin{array}{c}\text { Samani } \\
\text { dates } \\
\text { (ripe stage) }\end{array}$ \\
\hline Physical characteristics & & \\
Average weight (g)/Fruit & 9.75 & 31.20 \\
Flesh weight \% & 97.5 & 89.7 \\
Pit weight \% & 2.5 & 10.3 \\
Flesh /pit ratio & 39.0 & 8.71 \\
T.S.S.\% & 20.1 & 24.8 \\
pH value & 6.41 & 6.86 \\
\hline Chemical characteristics & & \\
Total sugars* \% & 64.46 & 72.34 \\
Reducing sugars* \% & 49.72 & 56.35 \\
Non-reducing sugars*\% & 14.74 & 15.99 \\
Crude fiber*\% & 5.46 & 3.65 \\
Ash*\% $\%$ phenol*(as tannic & 2.65 & 2.17 \\
Total \% & 3.92 & 0.97 \\
acid) \% & & \\
Total acidity*(as malic acid) \% & 0.364 & 0.159 \\
Moisture content \% & 72.93 & 69.12 \\
\hline
\end{tabular}

* On dry weight basis.
Table (3): Effect of blanching time on the physical and chemical characteristics of unpollinated Siwi dates.

\begin{tabular}{|l|c|c|c|}
\hline \multirow{2}{*}{\multicolumn{1}{|c|}{ Characteristics }} & \multicolumn{3}{|c|}{$\begin{array}{c}\text { Time of blanching } \\
\text { (min) at 100 }\end{array}$} \\
\cline { 2 - 4 } & $\mathbf{1 5}$ & $\mathbf{3 0}$ & $\mathbf{4 5}$ \\
\hline T.S.S. \% & 19.4 & 21.9 & 24.0 \\
pH value & 5.75 & 5.69 & 5.42 \\
Total sugars*\% & 64.01 & 65.35 & 66.82 \\
Reducing sugars*\% & 50.81 & 51.92 & 53.25 \\
Non-reducing sugars*\% & 13.20 & 13.43 & 13.57 \\
Ash* \% & 2.61 & 2.59 & 2.43 \\
Total phenols*(as tannic & 2.44 & 1.59 & 1.23 \\
acid) \% & & & \\
Total acidity*( as malic & 0.411 & 0.553 & 0.555 \\
acid )\% & & & \\
Moisture content \% & 78.76 & 73.25 & 73.12 \\
\hline
\end{tabular}

*on dry weight basis. 
Table (4): Physical and chemical properties of date jam.

\begin{tabular}{|l|c|c|c|c|c|c|}
\hline Treatments & Control & $\mathbf{1}$ & $\mathbf{2}$ & $\mathbf{3}$ & $\mathbf{4}$ & $\mathbf{5}$ \\
\hline T.S.S. \% & 67.9 & 68.4 & 67.9 & 68.2 & 42.9 & 29.8 \\
pH value & 4.87 & 4.15 & 4.17 & 4.41 & 4.55 & 4.52 \\
Viscosity (poise) & 53.4 & 153.0 & 151.2 & 73.0 & 50.0 & 46.4 \\
Total sugars* \% & 86.24 & 84.61 & 84.01 & 86.83 & 74.71 & 65.89 \\
Reducing sugars* \% & 46.65 & 21.84 & 21.23 & 24.11 & 31.95 & 60.38 \\
Non-reducing sugars*\% & 39.59 & 62.77 & 62.78 & 62.72 & 42.76 & 5.51 \\
Crude fiber* \% & 0.43 & 1.04 & 1.08 & 0.61 & 1.41 & 1.99 \\
Ash* \% & 0.51 & 0.31 & 0.33 & 0.41 & 0.817 & 1.33 \\
Total phenols*( as tannic acid) \% & 0.204 & 0.270 & 0.259 & 0.231 & 0.335 & 0.767 \\
Total acidity* (as malic acid) \% & 0.192 & 0.249 & 0.257 & 0.229 & 0.318 & 0.553 \\
Moisture content\% & 27.51. & 25.07 & 24.76 & 26.28 & 48.99 & 61.18 \\
\hline
\end{tabular}

*On dry weight basis.

Table (5): Sensory evaluation of date jam after processing (means of sensory score*)

\begin{tabular}{|c|c|c|c|c|c|}
\hline $\begin{array}{c}\text { Jam } \\
\text { Treatments }\end{array}$ & Color & Taste & Texture & Flavor & $\begin{array}{c}\text { Overall } \\
\text { acceptability }\end{array}$ \\
\hline & & & & & $\mathrm{a}$ \\
Control & $8.25 \pm 0.71$ & $8.35 \pm 0.97$ & $8.35 \pm 0.66$ & $7.75 \pm 0.67$ & $8.17 \pm 0.28$ \\
\hline & $\mathrm{c}$ & $\mathrm{b}$ & $\mathrm{b}$ & $\mathrm{b}$ & $\mathrm{c}$ \\
1 & $6.45 \pm 0.89$ & $6.9 \pm 1.10$ & $6.8 \pm 0.71$ & $6.75 \pm 0.63$ & $6.72 \pm 0.19$ \\
\hline & $\mathrm{bc}$ & $\mathrm{a}$ & $\mathrm{b}$ & $\mathrm{ab}$ & $\mathrm{bc}$ \\
2 & $6.6 \pm 0.80$ & $7.7 \pm 0.88$ & $6.85 \pm 0.47$ & $7.65 \pm 0.91$ & $7.25 \pm 0.62$ \\
\hline & $\mathrm{a}$ & $\mathrm{a}$ & $\mathrm{a}$ & $\mathrm{a}$ & $\mathrm{ab}$ \\
3 & $7.9 \pm 0.99$ & $8.3 \pm 0.82$ & $8.25 \pm 0.67$ & $7.75 \pm 0.42$ & $8.05 \pm 0.26$ \\
\hline & $\mathrm{ab}$ & $\mathrm{a}$ & $\mathrm{a}$ & $\mathrm{ab}$ & $\mathrm{abc}$ \\
4 & $7.5 \pm 0.52$ & $7.9 \pm 0.77$ & $7.8 \pm 0.91$ & $6.95 \pm 0.86$ & $7.53 \pm 0.42$ \\
\hline & $\mathrm{ab}$ & $\mathrm{ab}$ & $\mathrm{ab}$ & $\mathrm{ab}$ & $\mathrm{abc}$ \\
& $7.45 \pm 0.67$ & $7.7 \pm 0.82$ & $7.65 \pm 0.71$ & $6.85 \pm 0.71$ & $7.41 \pm 0.39$ \\
\hline
\end{tabular}

*Means with the same letter are not significantly different at 0.05 level of significance.

Control treatment: Samani date+ sucrose (1:1wt/wt ratio).

Treatment 1: Unpollinated Siwi date +sucrose (1:1wt/wt ratio)

Treatment 2: Unpollinated Siwi date +sucrose $(1: 1 \mathrm{wt} / \mathrm{wt}$ ratio $)+0.5 \mathrm{~g}$ cloves $/ 100 \mathrm{~g}$ date.

Treatment 3: Samani date +unpollinated Siwi date+ sucrose (1:1:2wt/wt/wt ratio).

Treatment 4: Samani date+ unpollinated Siwi date + sucrose $(1: 1: 1 \mathrm{wt} / \mathrm{wt} / \mathrm{wt}$ ratio $)+$ aspartame representing sweetening power of $1 \mathrm{wt}$ sucrose.

Treatment 5: Samani date+unpollinated Siwi date+ aspartame $(1: 1 \mathrm{wt} / \mathrm{wt}$ ratio $)+$ aspartame representing sweetening powers of 2 wt sucrose.

Table (6): Minerals content of dates, and Jam (mg/100g dry weight)

\begin{tabular}{|l|c|c|c|}
\hline Samples & $\begin{array}{c}\text { Unpollinated } \\
\text { Siwi dates } \\
\text { (at khalal } \\
\text { stage) }\end{array}$ & $\begin{array}{c}\text { Samani } \\
\text { dates } \\
\text { (at ripe } \\
\text { stage) }\end{array}$ & $\begin{array}{c}\text { Jam date } \\
\text { treatment } \\
(3)\end{array}$ \\
\hline Potassium & 849.160 & 728.560 & 88.910 \\
\hline Sodium & 14.080 & 16.970 & 2.590 \\
\hline Calcium & 6.449 & 4.928 & 0.992 \\
\hline Iron & 3.535 & 2.340 & 0.607 \\
\hline Zinc & 0.581 & 0.340 & 0.100 \\
\hline Copper & 0.444 & 0.215 & 0.096 \\
\hline
\end{tabular}


from unpollinated Siwi date was characterized by a high level of non-reducing sugars, crude fibers, total phenols and viscosity. Using cloves in the preparation of date jam treatment (2) did not affect the physical and chemical properties of the jam. Jam treatment (3) prepared by equal parts of unpollinated Siwi date and Samani date showed lower levels of viscosity and fiber content than those of the treatments prepared with unpollinated Siwi date only. From the results in Table (4) it could be concluded that the total sugar content of jam treatments (4 and 5) prepared by replacing 50 and $100 \%$ of the sucrose with artificial sweetener aspartame according to its sweetness were 37.7 and $25.6 \%$ (Fresh weight),respectively. These results are in accordance with the Egyptian Standards (2002) for food for special dietary usesjam reduced of calories. The same results for treatment (5) pointed out to the high fiber content $1.99 \%$ (on dry weight), since date fruits in this case were the sole source of solids in the jam.

The results in Table (5) indicate that the texture scores of date jam (control treatment) were significantly higher than those of the date jam of the treatments (1) and (2) due to their higher fiber content. These treatments ( 1 and 2 ) were prepared from unpollinated Siwi dates only and the peels of the dates were not removed because the flesh was lost during the separation of peels. Also, the same results in Table (5) show that texture scores of date jam treatments (control, 3, 4 and 5) had no significant differences. The presence of peeled Samani dates at the ripe stage gave the jam a soft texture. None of the jam was judged to be hard. Also, the same results in Table (5) indicate that taste scores of jam (treatments, control, 2, 3, 4, and 5) were significantly higher than that of treatment, 1 due to the addition of Samani date at the ripe stage, cloves and artificial sweetener. Results in Table (5) show that color and flavor of jam treatments (control, 2 3, 4, and 5) were significantly higher than that of jam (treatment, 1).From the results in Table (5) it could be indicated that the overall acceptability of date jam prepared with unpollinated Siwi and Samani dates(1:1), regardless of replacing sucrose in jam, was better significantly than that of jam prepared with unpollinated Siwi dates only .In other words, these treatments were acceptable and stored at room temperature.

Mineral salts are important in human nutrition and necessary for vital activities of human body. Dates are considered to be a source of mineral salts. Data in Table (6) show mineral contents of unpollinated Siwi dates at the khalal stage, Samani dates at the ripe stage and Jam treatment (3). From these data it could be noticed that the unpollinated Siwi dates contained higher concentrations of potassium, calcium, iron, zinc and copper than Samani dates. Youssef et al.(1998) reported that the mineral contents of Saidy date decreased during maturity till it reached the tamr stage .From the results in Table (6) it is observed that ,the levels of mineral content of date jam were lower than those of the dates regardless of date used type due to the sucrose added during jam processing .

The effect of storage at room temperature for 6 months on physical and chemical properties of the selected treatments that achieved high sensory scores (overall acceptability) are tabulated in Table (7).

From these data, it could be noticed that the gradual decrease in total acidity of all jam samples during storage. This decrement in total acidity might be attributed to the interaction between acidic components naturally present or externally added (citric acid) and other chemical ingredients of fruits (EL Sheik, 1999).Results in Table (7) show that non-reducing sugars decreased during storage of date jam. These results could be due to hydrolysis of the non-reducing sugars in the acidic media during storage. Also, the results in Table (7) indicate that total sugars slightly decreased during storage of date jam. These results could be related to the browning reaction between free amino acids and sugars (Reynolds, 1965). Results in Table (7) indicate that the viscosity and total phenols were gradually decreased during storage at room temperature. These results are in accordance with those reported by El Sheik (1999) and Piga et al.(2003).

Table (8) shows the effect of storage of date jam treatments at room temperature on sensory evaluation. From these data, it could be noticed that using the unpollinated Siwi dates for jam manufacturing (treatment 3) did not affect negatively color, taste, texture and flavor of the jam compared with the control treatment even after 6 months of storage at room temperature. Using the artificial sweetener, aspartame instead of sucrose during manufacturing of jam (treatments 4 and 5) caused significant decrease in color, taste, texture and flavor of the jam after 6 months of storage at room temperature compared with the control treatment.Although the score of the overall acceptability of the Jam (treatments 4 and 5) was the lowest amoung the other prepared jam, overall acceptability of these treatments were acceptable (overall acceptability $=7.05$ and 6.75) by the panelists even after 6 months of storage. Also, the same Table ( 8 ) indicates that 
Table (7): Effect of storage at room temperature on physical and chemical properties of date jam (on dry weight basis)

\begin{tabular}{|c|c|c|c|c|c|c|c|c|c|c|c|c|}
\hline \multirow{2}{*}{$\begin{array}{l}\text { Treatments } \\
\text { Storage period (months) } \\
\text { Properties }\end{array}$} & \multicolumn{3}{|c|}{ Control } & \multicolumn{3}{|c|}{3} & \multicolumn{3}{|c|}{4} & \multicolumn{3}{|c|}{5} \\
\hline & Zero time & 3 & 6 & Zero time & 3 & 6 & Zero time & 3 & 6 & Zero time & 3 & 6 \\
\hline Viscosity by (Poise) & 53.40 & 52.33 & 51.81 & 73.00 & 71.18 & 70.32 & 50.00 & 48.50 & 47.77 & 46.40 & 44.62 & 43.50 \\
\hline $\mathrm{pH}$ value & 4.87 & 4.93 & 4.97 & 4.41 & 4.48 & 4.52 & 4.55 & 4.64 & 4.69 & 4.52 & 4.63 & 4.68 \\
\hline T.S.S. \% & 67.50 & 66.80 & 66.60 & 68.20 & 67.80 & 67.40 & 42.90 & 42.50 & 42.10 & 29.80 & 29.40 & 29.10 \\
\hline Reducing sugars * \% & 46.65 & 47.44 & 47.96 & 24.11 & 24.56 & 24.85 & 31.95 & 32.75 & 33.18 & 60.38 & 62.19 & 63.12 \\
\hline Non-reducing sugars $* \%$ & 39.59 & 38.20 & 37.42 & 62.72 & 61.66 & 61.11 & 42.76 & 41.36 & 40.65 & 5.51 & 3.04 & 1.79 \\
\hline Total sugars* \% & 86.24 & 85.64 & 85.38 & 86.83 & 86.22 & 85.96 & 74.71 & 74.11 & 73.83 & 65.89 & 65.23 & 64.91 \\
\hline Total phenols $* \%($ as tannic acid $)$ & 0.204 & 0.172 & 0.187 & 0.231 & 0.203 & 0.184 & 0.335 & 0.284 & 0.249 & 0.767 & 0.613 & 0.521 \\
\hline Total acidity* \%( as malic acid) & 0.192 & 0.190 & 0.188 & 0.229 & 0.226 & 0.223 & 0.318 & 0.312 & 0.308 & 0.553 & 0.539 & 0.533 \\
\hline Moisture content $\%$ & 27.51 & 27.28 & 27.14 & 26.28 & 26.07 & 25.96 & 48.99 & 48.50 & 48.16 & 61.18 & 60.15 & 59.55 \\
\hline
\end{tabular}

$*$ on dry weight basis
Control treatment $\quad$ : Control: Samani date+ sucrose $(1: 1 \mathrm{wt} / \mathrm{wt}$ ratio).

Treatment 3: Samani date +unpollinated Siwi date+ sucrose $(1: 1: 2 \mathrm{wt} / \mathrm{wt} / \mathrm{wt}$ ratio $)$.
Treatment 4: Samani date+ unpollinated Siwi date + sucrose $(1: 1: 1 \mathrm{wt} / \mathrm{wt} / \mathrm{wt}$ ratio $)$ +aspartame representing sweetening power of $1 \mathrm{wt}$ sucrose.

Treatment 4: Samani date+ unpollinated Siwi date + sucrose $(1: 1: 1 \mathrm{wt} / \mathrm{wt} / \mathrm{wt}$ ratio $)+$ aspartame representing sweetening power of $1 \mathrm{wt}$ sucro
Treatment 5amani date+unpollinated Siwi date+ aspartame $(1: 1 \mathrm{wt} / \mathrm{wt}$ ratio $)+$ aspartame representing sweetening power of $2 \mathrm{wt}$ sucrose.

Table (8): Effect of storage at room temperature on sensory evaluation of date jam (means of sensory score*).

\begin{tabular}{|c|c|c|c|c|c|c|c|c|c|c|c|c|}
\hline Treatments & \multicolumn{3}{|c|}{ Control } & \multicolumn{3}{|c|}{3} & \multicolumn{3}{|c|}{4} & \multicolumn{3}{|c|}{5} \\
\hline $\begin{array}{l}\text { Storage period (month) } \\
\text { Properties }\end{array}$ & Zero time & 3 & 6 & Zero time & 3 & 6 & Zero time & 3 & 6 & Zero time & 3 & 6 \\
\hline Color & $\begin{array}{c}\mathrm{a} \\
8.25 \pm 0.71\end{array}$ & $\begin{array}{c}\mathrm{a} \\
8.15 \pm 0.94\end{array}$ & $\begin{array}{c}a b \\
8.00 \pm 0.84\end{array}$ & $\begin{array}{c}a b \\
7.9 \pm 0.99\end{array}$ & $\begin{array}{c}\text { abc } \\
7.8 \pm 0.91\end{array}$ & $\begin{array}{c}\text { abc } \\
7.70 \pm 0.82\end{array}$ & $\begin{array}{c}a b c \\
7.50 \pm 0.52\end{array}$ & $\begin{array}{c}\mathrm{abc} \\
7.30 \pm 0.67\end{array}$ & $\begin{array}{c}\text { bc } \\
7.0 \pm 0.74\end{array}$ & $\begin{array}{c}\text { abc } \\
7.45 \pm 0.59\end{array}$ & $\begin{array}{c}a b c \\
7.20 \pm 0.75\end{array}$ & $\begin{array}{c}c \\
6.80 \pm 0.67\end{array}$ \\
\hline Taste & $\begin{array}{c}\mathrm{a} \\
8.35 \pm 0.97\end{array}$ & $\begin{array}{c}\mathrm{a} \\
8.30 \pm 0.85\end{array}$ & $\begin{array}{c}\mathrm{a} \\
8.25 \pm 1.06\end{array}$ & $\begin{array}{c}\mathrm{a} \\
8.3 \pm 0.82\end{array}$ & $\begin{array}{c}\mathrm{a} \\
8.25 \pm 0.67\end{array}$ & $\begin{array}{c}\mathrm{a} \\
8.05 \pm 0.72\end{array}$ & $\begin{array}{c}\mathrm{a} \\
7.90 \pm 0.77\end{array}$ & $\begin{array}{c}\mathrm{ab} \\
7.70 \pm 0.53\end{array}$ & $\begin{array}{c}a b \\
7.30 \pm 0.91\end{array}$ & $\begin{array}{c}\mathrm{ab} \\
7.70 \pm 0.84\end{array}$ & $\begin{array}{c}\mathrm{ab} \\
7.40 \pm 0.61\end{array}$ & $\begin{array}{c}\mathrm{b} \\
6.80 \pm 0.77\end{array}$ \\
\hline Texture & $\begin{array}{c}\mathrm{a} \\
8.35 \pm 0.66\end{array}$ & $\begin{array}{c}a b c \\
8.15 \pm 0.96\end{array}$ & $\begin{array}{c}\text { abc } \\
8.05 \pm 0.77\end{array}$ & $\begin{array}{c}a b \\
8.25 \pm 0.67\end{array}$ & $\begin{array}{c}a b c \\
8.05 \pm 0.72\end{array}$ & $\begin{array}{c}\text { abc } \\
7.99 \pm 0.71\end{array}$ & $\begin{array}{c}a b c \\
7.80 \pm 0.91\end{array}$ & $\begin{array}{c}\mathrm{abc} \\
7.50 \pm 0.88\end{array}$ & $\begin{array}{c}\text { bc } \\
7.25 \pm 0.85\end{array}$ & $\begin{array}{c}\text { abc } \\
7.65 \pm 0.91\end{array}$ & $\begin{array}{c}\text { abc } \\
7.45 \pm 0.79\end{array}$ & $\begin{array}{c}\mathrm{c} \\
7.10 \pm 0.77\end{array}$ \\
\hline Flavor & $\begin{array}{c}\mathrm{a} \\
7.75 \pm 0.67\end{array}$ & $\begin{array}{c}a b \\
7.65 \pm 0.70\end{array}$ & $\begin{array}{c}a b c \\
7.50 \pm 0.88\end{array}$ & $\begin{array}{c}\mathrm{a} \\
7.75 \pm 0.42\end{array}$ & $\begin{array}{c}\text { ab } \\
7.65 \pm 0.47\end{array}$ & $\begin{array}{c}\text { abc } \\
7.50 \pm 0.70\end{array}$ & $\begin{array}{c}\text { abcd } \\
6.95 \pm 0.86\end{array}$ & $\begin{array}{c}\text { bcd } \\
7.75 \pm 0.82\end{array}$ & $\begin{array}{c}\mathrm{cd} \\
6.65 \pm 0.65\end{array}$ & $\begin{array}{c}\text { abcd } \\
6.85 \pm 0.71\end{array}$ & $\begin{array}{c}\mathrm{cd} \\
6.60 \pm 0.73\end{array}$ & $\begin{array}{c}\mathrm{d} \\
6.30 \pm 0.78 \\
\end{array}$ \\
\hline Overall acceptability & $\begin{array}{c}\mathrm{a} \\
8.17 \pm 0.28\end{array}$ & $\begin{array}{c}\mathrm{ab} \\
8.09 \pm 0.30\end{array}$ & $\begin{array}{c}\mathrm{abc} \\
8.0 \pm 0.35\end{array}$ & $\begin{array}{c}a b \\
8.05 \pm 0.26\end{array}$ & $\begin{array}{c}\mathrm{abc} \\
7.93 \pm 0.26\end{array}$ & $\begin{array}{c}\text { abcd } \\
7.81 \pm 0.25\end{array}$ & $\begin{array}{c}\text { abcde } \\
7.53 \pm 042\end{array}$ & $\begin{array}{c}\text { cdef } \\
7.31 \pm 0.41\end{array}$ & $\begin{array}{c}\text { ef } \\
7.05 \pm 0.29\end{array}$ & $\begin{array}{c}\text { bcdef } \\
7.41 \pm 0.39\end{array}$ & $\begin{array}{c}\text { bcdef } \\
7.43 \pm 0.31\end{array}$ & $\begin{array}{c}\mathrm{f} \\
6.75 \pm 0.33\end{array}$ \\
\hline
\end{tabular}

*Means with the same letter are not significantly different at 0.05 level of significance.

Control : Control: Samani date+ sucrose (1:1wt/wt ratio).

Treatment 3: Samani date +unpollinated Siwi date+ sucrose $(1: 1: 2 \mathrm{wt} / \mathrm{wt} / \mathrm{wt}$ ratio $)$

Treatment 4: Samani date+ unpollinated Siwi date + sucrose $(1: 1: 1 \mathrm{wt} / \mathrm{wt} / \mathrm{wt}$ ratio $)+$ aspartame representing sweeteners of $1 \mathrm{wt}$ sucrose.

Treatment 5: Samani date+unpollinated Siwi date+ aspartame $(1: 1 \mathrm{wt} / \mathrm{wt}$ ratio) + aspartame representing sweeteners of $2 \mathrm{wt}$ sucrose. 
there was no significant difference in the overall acceptability scores of the date jam prepared with Samani dates only (control treatment) and that prepared with Samani dates + unpollinated Siwi dates $(1: 1, w t / w t)$ even after 6 months of storage of the jam at room temperature. Generally the utilization of unpollinated Siwi date with Samani date in jam processing, gave quality attributes resembling that found when Samani date was used.

\section{REFERENCES}

Abbas M.C.(1982). Physiological Studies Concerning the Effect of Some Plant Regulators on Date Fruits. M.Sc. Thesis, Horticulture Dept., Fac. of Agric., Ain Shams Univ., Egypt.

A.O.A.C. (2000). Official Methods of Analysis of the Association of Official Analytical Chemists International. Published by the Association of Official Analytical Chemist's International, Maryland 20877-2417-USA.

Arab Organization for Agricultural Development(2005). Arab Agricultural Statistics. Year Book, Vol. 25:76

Assous M.T.M. (1999). Production and Evaluation of Siwi Date Syrup (dibis). M.Sc. Thesis, Food Sci. Technology Dept., Fac. of Agric., Cairo Univ., Egypt.

Bate-Smith E.C.(1977).Astringent tannins of acer species. Phytochem.,16,1421.

Dowson V.H. W. and Aten A. (1962).Dates : Handling, Processing and Packing. F.A.O Agricultural Development paper No. 72. Food and Agriculture Organization of the United Nations, Rome.

Egyptian Standards (2002). Food for Special Dietary Uses-jam Reduced of Calories. Egyptian Organization for Standardization and Quality Control, Arab Republic of Egypt ES:1433.

El Sheik D.M. (1999).Production and Evaluation of Some Low Calorie Jams. M.Sc. Thesis, Food Sci. Technology Dept., Fac. of Agric., Cairo Univ., Egypt.

Hamed S.H. (1980).Chemical and Technological Studies on the Preservation of Some Fruits and Vegetables and their Products. M.Sc. Thesis, Food Sci. Technology Dept., Fac. of Agric., Monofia Univ., Egypt.

Hassan F.R.H.(1995).Chemical and Technological Studies on Fruit Drying of Some Fig Cultivars. M.Sc. Thesis, Food Sci. Technology Dept., Fac. of Agric., Cairo Univ., Egypt.
Maier V.P. and Metzler D.M. (1965). Changes in individual date polyphenols and their relation to browning. J. Food Sci. 30 (1) 80 84.

Ministry of Agriculture and Land Reclamation (2006). Agricultural Statistical , part (2). Central Administration for Economics. Dokki, Egypt .

Nezam El-Din A.M.M. (1988). Studies on Harmful Substances in Some Foods. Ph.D. Thesis, Faculty of Agric. Moshtohor, Zagazig Univ., Egypt.

Nezam El-Din A.M.M. (1996). Study on the utilization of unpollinated Siwi dates (Shees). Egypt. J. Food Sci., 24 (2): 147165.

Piga A., Delcaro A., Pinna I. and Agabbio M.(2003). Changes in ascorbic acid, polyphenols content and antioxidant activity in minimally processed Cactus pear fruits. Lebensm-Wiss.U. Technol.36:257-262.

Ragab M.H.H., El-Tabey Shehata A.M. and Sedky A. (1956).Studies on Egyptian dates. II. Chemical changes during development and ripening of six varieties. Food Technology, September, 407-410.

Ranganna S. (1977). Manual of Analysis of Fruit and Vegetable Products. Tata McGrawHill Publishing Company Limited, New Delhi.

Reynolds T.M.(1965).Chemistry of non zymatic browning. Advances in Food Research, $14: 229$

Rizk S.A.Y. (1987).Studies on the Effect of Fertilization on Date Palm Production. Ph.D. Thesis, Horticulture Dept., Fac. of Agric., Ain Shams Univ., Egypt.

Rygg G.L.(1946). Utilization of unpollinated Deglet Noor dates. Date Growers' Inst. 23,36-38.

Sawaya $\square$ W.N.,Khalil J.K., Khatchdourian H.A., Safi W.M., and Mashadi A.S. (1982) . Sugars, tannins and some vitamin contents of twenty-five date cultivars grown in Saudi Arabia at the khalal (mature color) and tamr (ripe) stages. . Proc. of the $1^{\text {st }}$ Symp. on Date Palm, 23-25March, King Faisal Univ., AlHassa, Saudi Arabia p. 468-478, (1983).

Snedecor G.W. and Cochran, W.G. (1980). Statistical Methods. $7^{\text {th }}$ Ed. Iowa Univ. Press Ames, Iowa, USA.

Swain T. and Hillis W.E. (1959). The phenolic constituents of Prunus domestica. 1- The quantitative analysis of phenolic constituents. J. Sci. Food Agric. 10: 63-6. 
Yousif A.K., Hassan B.T .,Saed B. T. ,Eila, M.Y.(1982).Studies on khalal matbuukh: Effect of khalal time picking on the physical, chemical and organoleptic properties of the produced khalal matbuukh. Proc. of the $1^{\text {st }}$ Symp. on Date Palm, 3-6
March, King Faisal Univ., Al-Hassa, Saudi Arabia p. 544-550, (1983).

Youssef M.K.E., Abou El-Hawa, S.H., Seleim, M.A. and Ramadan,B.R.(1998).Evaluation of chemical composition of various types of upper Egypt dates. Assiut J. of Agric. Sci., 29 (3) : 33-52.

\section{إنتاج وتقييم المربى المصنعة من البلح السيوي غير المخصب (الثيص) \\ مصطفى طله محمدى عسوس ، عمر راضى لحمل مسعود ، محمل عبد الرحمن عطوه}

معهد بحوث تكنولوجيا الأغذية ، مركز البحوث الزراعية ، الجيزة ، مصر

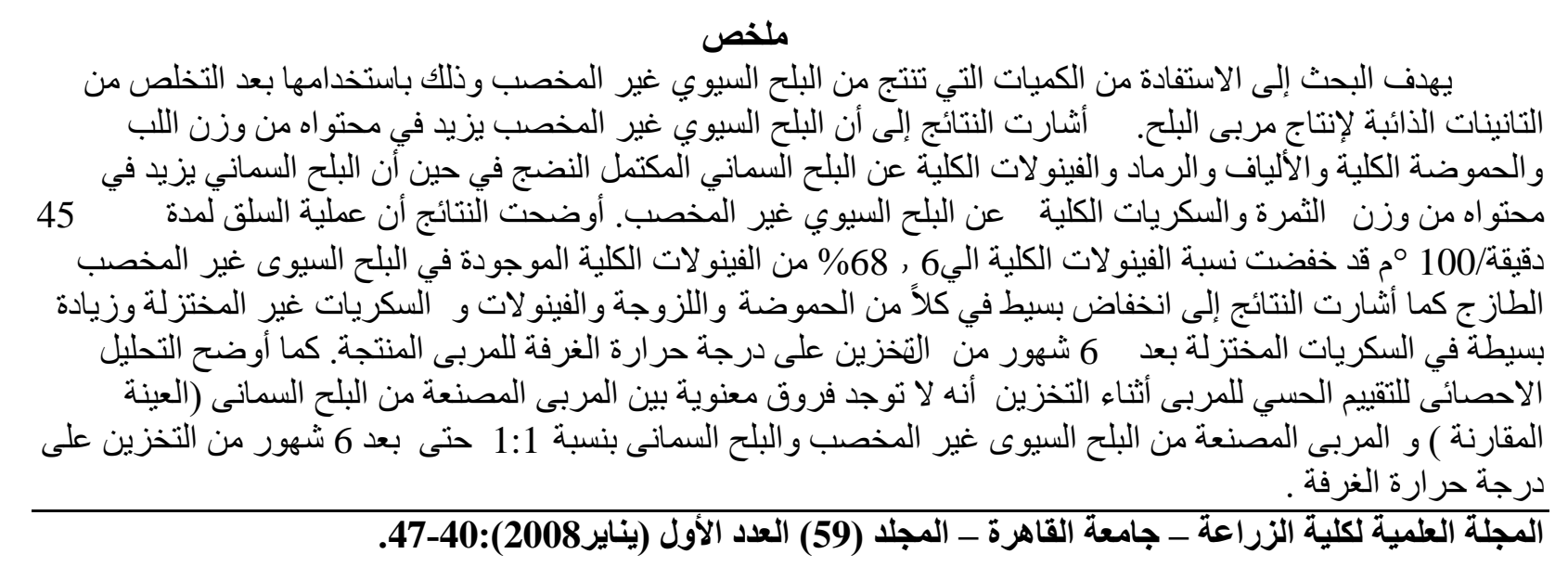

